University of Nebraska - Lincoln

DigitalCommons@University of Nebraska - Lincoln

USDA Forest Service / UNL Faculty Publications U.S. Department of Agriculture: Forest Service -National Agroforestry Center

2012

\title{
Effects of ungulate herbivory on aspen, cottonwood, and willow development under forest fuels treatment regimes
}

\author{
Bryan A. Endress \\ Oregon State University, bendress@sandiegozoo.org \\ Michael J. Wisdom \\ USDA Forest Service, mwisdom@fs.fed.us \\ Martin Vavra \\ USDA Forest Service, mvavra@fs.fed.us \\ Catherine G. Parks \\ USDA Forest Service, cparks01@fs.fed.us \\ Brian L. Dick \\ USDA Forest Service, bdick@fs.fed.us \\ See next page for additional authors
}

Follow this and additional works at: https://digitalcommons.unl.edu/usdafsfacpub

Part of the Forest Sciences Commons

Endress, Bryan A.; Wisdom, Michael J.; Vavra, Martin; Parks, Catherine G.; Dick, Brian L.; Naylor, Bridgett J.; and Boyd, Jennifer M., "Effects of ungulate herbivory on aspen, cottonwood, and willow development under forest fuels treatment regimes" (2012). USDA Forest Service / UNL Faculty Publications. 164. https://digitalcommons.unl.edu/usdafsfacpub/164

This Article is brought to you for free and open access by the U.S. Department of Agriculture: Forest Service -National Agroforestry Center at DigitalCommons@University of Nebraska - Lincoln. It has been accepted for inclusion in USDA Forest Service / UNL Faculty Publications by an authorized administrator of DigitalCommons@University of Nebraska - Lincoln. 


\section{Authors}

Bryan A. Endress, Michael J. Wisdom, Martin Vavra, Catherine G. Parks, Brian L. Dick, Bridgett J. Naylor, and Jennifer M. Boyd 


\title{
Effects of ungulate herbivory on aspen, cottonwood, and willow development under forest fuels treatment regimes
}

\author{
Bryan A. Endress ${ }^{\mathrm{a}, *}$, Michael J. Wisdom ${ }^{\mathrm{b}}$, Martin Vavra ${ }^{\mathrm{b}}$, Catherine G. Parks ${ }^{\mathrm{b}}$, Brian L. Dick ${ }^{\mathrm{b}}$, \\ Bridgett J. Naylor ${ }^{\mathrm{b}}$, Jennifer M. Boyd ${ }^{\mathrm{b}}$ \\ a Department of Forest Ecosystems and Society, Oregon State University, Corvallis, OR 97331, USA \\ ${ }^{\mathrm{b}}$ USDA Forest Service, Pacific Northwest Research Station, 1401 Gekeler Lane, La Grande, OR 97850, USA
}

\section{A R T I C L E I N F O}

\section{Article history:}

Received 29 January 2012

Received in revised form 16 March 2012

Accepted 19 March 2012

Available online 19 April 2012

\section{Keywords:}

Chronic disturbances

Fire

Fuels reduction

Grazing

Ungulates

Forest dynamics

\begin{abstract}
A B S T R A C T
Herbivory by domestic and wild ungulates can dramatically affect vegetation structure, composition and dynamics in nearly every terrestrial ecosystem of the world. These effects are of particular concern in forests of western North America, where intensive herbivory by native and domestic ungulates has the potential to substantially reduce or eliminate deciduous, highly palatable species of aspen (Populus tremuloides), cottonwood (Populus trichocarpa), and willow (Salix spp.). In turn, differential herbivory pressure may favor greater establishment of unpalatable conifers that serve as ladder fuels for stand-replacing fires. The resulting high fuel loads often require silvicultural fuels reductions to mitigate fire risk, which in turn may facilitate additional recruitment of deciduous species but also additional herbivory pressure. Potential interactions of ungulate herbivory with episodic disturbances of silviculture, fire, and other land uses are not well documented, but are thought to operate synergistically to affect forest dynamics. We evaluated individual and joint effects of ungulate herbivory and fuels reduction treatments in grand fir (Abies grandis) and Douglas-fir (Psuedotsuga menziezii) forests that dominate large areas of interior western North America. We applied fuels reduction treatments of mechanical thinning and prescribed fire and then evaluated the responses of aspen, cottonwood, and willow species to these treatments $(N=3)$ versus areas of no treatment $(N=3)$, and to exclusion from ungulate herbivory versus areas subjected to extant herbivory by free-ranging cattle (Bos taurus), elk (Cervus elaphus), and mule deer (Odocoileus hemionus). Densities of deciduous species were $>4$ times higher in response to fuels reduction treatments ( 84.4 individuals/ha) compared to areas of no treatment (19.7 individuals/ha). Additionally, when ungulates were excluded from fuels treated sites, the density of cottonwood was $>5$ times higher (122.5 individuals/ha) than fuels treated sites subjected to extant herbivory (24.3 individuals/ha). Similarly, densities of Populus spp. and Salix spp. were $>3$ times higher (211.6 individuals/ha) on fuels treated sites excluded from ungulate herbivory versus fuels treated sites subjected to extant herbivory (66.1 stems/ha). Deciduous species subjected to extant ungulate herbivory also were significantly lower in height, canopy surface area, and canopy volume than the same species inside the ungulate exclosures. Recruitment and long-term survival of aspen, cottonwood, and willow species in coniferous forests of interior western North America require a combination of episodic disturbances such as silviculture and fire to facilitate deciduous plant recruitment, followed by reductions in grazing pressure by domestic and wild ungulates during the time intervals between episodic disturbances to facilitate plant establishment, growth and survival.
\end{abstract}

() 2012 Elsevier B.V. All rights reserved.

\section{Introduction}

Ungulate herbivory is a chronic disturbance that can have dramatic effects on vegetation dynamics and other ecological

\footnotetext{
* Corresponding author. Current address: Division of Applied Plant Ecology, Institute for Conservation Research, San Diego Zoo Global, 15600 San Pasqual Valley Road, Escondido, CA 92027, USA. Tel.: +1 760291 5486; fax: +1 7602915428.

E-mail addresses: bendress@sandiegozoo.org (B.A. Endress), mwisdom@fs.fed.us (M.J. Wisdom), mvavra@fs.fed.us (M. Vavra), cparks01@fs.fed.us (C.G. Parks), bdick@fs.fed.us (B.L. Dick), bnalyor@fs.fed.us (B.J. Naylor), jmboyd@fs.fed.us (J.M. Boyd).
}

processes in ecosystems throughout the world (Díaz et al., 2007). When ungulates suppress or eliminate preferred forage plants in favor of less preferred and less digestible plants, nutrient cycling and energy flow through an ecosystem can change substantially (Pastor et al., 1993; Pastor and Cohen, 1997; Schoenecker et al., 2004). A myriad of above- and below-ground processes can be affected (Wardle, 2002), including substantial changes in ecosystem productivity and the associated floral and faunal communities (Bormann and Gordon, 1989; Knops et al., 2000; Riggs et al., 2000; Schoenecker et al., 2004; Tiedemann and Berndt, 1972). Habitats and associated faunal communities can change entirely, 
often with little perception or recognition that profound changes have occurred (e.g., Augustine et al., 1998; Côté et al., 2004; deCalesta, 1994; McShea and Rappole, 2000). Consequently, ungulates in many ecosystems are considered "keystone species," capable of causing substantial and sometime irreversible changes in ecosystem processes and properties (Alverson and Waller, 1997; Sinclair, 2003; Smit and Putman, 2011).

Despite the documented effects of ungulate herbivory on vegetation dynamics and other ecosystem processes, many specific effects are difficult to evaluate for at least three reasons (Wisdom et al., 2006). First, both domestic and wild ungulates have grazed most ecosystems for hundreds or sometimes thousands of years as chronic, background disturbances, with long-term effects that often cannot be detected over short time periods. Second, the combination of herbivory by domestic and wild ungulates, with varying densities of ungulate species over different seasons of each year, adds tremendous complexity to research designs needed to evaluate the individual and combined effects of different ungulates. And finally, nearly all effects of ungulate herbivory interact with episodic disturbances of fire, drought, insect herbivory, and human land uses that occur on the same landscapes as ungulates (Vavra et al., 2007a,b; Weisberg and Bugmann, 2003). The interactions of chronic ungulate herbivory with more recognizable episodic disturbances are difficult to assess, requiring manipulative, controlled experiments that are logistically demanding to implement over the long time periods required to obtain meaningful results (Wisdom et al., 2006).

These research challenges are particularly relevant to forests of western North America, where research on the combined effects of herbivory by domestic and wild ungulates on vegetation dynamics and other ecological processes is not well developed (Wisdom et al., 2006). Yet, high densities of wild and domestic ungulates, particularly cattle (Bos spp.), elk (Cervus elaphus), and mule deer (Odocoileus hemionus), are present throughout forests of western North America (Wisdom and Thomas, 1996), and herbivory by these ungulates can substantially affect structure and function of these ecosystems (Hobbs, 1996). Moreover, the episodic disturbances of fire, silviculture, insect herbivory, and drought are common to these forests, and few studies have evaluated the interactions of episodic disturbances with ungulate herbivory (Wisdom et al., 2006).

If wild and domestic ungulates are capable of altering vegetation development and associated ecosystem properties, the forage species most preferred by ungulates should be expected to change rapidly in structure and density in response to intensive ungulate herbivory, especially following episodic disturbances that favor establishment of forage species preferred by ungulates (Vavra et al., 2004a,b, 2007a,b). In western North America, many species of deciduous shrubs and trees provide extremely high nutritional value as forage for ungulates (Canon et al., 1987; Cook, 2002). Deciduous species include aspen (Populus tremuloides), cottonwood (Populus trichocarpa), and willow (Salix spp.), all of which are strongly selected by cattle, elk, and mule deer in both upland forests and riparian communities (Beschta, 2005; Brookshire et al., 2002; Kay, 1997a,b; Ripple and Beschta, 2003; White et al., 1996). Strong grazing pressure by cattle, elk, and mule deer on aspen, cottonwood, and willow species, often combined with longterm fire suppression, is considered a major contributor to the widespread decline of these deciduous plant species and associated plant communities across millions of hectares in western North America (Bartos, 2001; Hann et al., 1997; Hessl and Graumlich, 2002). The resulting changes in forest composition and structure have reduced habitat for a variety of animal species across vast areas (Bartos, 2001; Hessl and Graumlich, 2002), and it is not known how readily these plant communities, which once contained an abundance of deciduous species, can recover with increased use of fire or other episodic disturbances to facilitate deciduous plant recruitment, combined with reductions in grazing pressure to facilitate deciduous plant growth and survival (Bartos, 2001; Fleischner, 1994; Hessl and Graumlich, 2002; Kay, 1997a,b).

Herbivory-induced changes in deciduous plant communities also have serious implications for fire management. Reduction or elimination of deciduous shrub and tree recruitment in forest understories as a result of intensive ungulate herbivory, promotes in-growth of unpalatable conifers by reducing competitive interactions between conifer and deciduous tree seedlings. These conifers then serve as ladder fuels for stand-replacement fires (Hobbs, 1996; Vavra et al., 2007a,b). This condition is magnified by long-term fire suppression, which further accelerates in-growth of coniferous ladder fuels in forest understories, further increasing the frequency, intensity and extent of stand-replacement fires (Hann et al., 1997; Quigley and Arbelbide, 1997; Vavra et al., 2007a,b).

The goal of our research was to document the effects of cattle, elk, and mule deer on the density and structural development of aspen, cottonwood, and willow species in western North American forests, and to evaluate the potential interactions of these herbivores with episodic disturbances of silviculture and fire. Our specific objectives were to: (1) document differences in recruitment, density, height, canopy area, and canopy volume of aspen, cottonwood, and willow species under complete exclusion from ungulates versus extant herbivory by cattle, elk, and mule deer; and (2) to evaluate the potential differences caused by herbivory following intensive fuels treatment reductions, using mechanical removal and prescribed fire, versus no fuels treatment reductions. Our research took place in grand fir (Abies grandis) and Douglas-fir (Pseudotsuga menziesii) forests, which dominate much of interior western North America, and where little knowledge exists regarding ungulate herbivory-episodic disturbance interactions (Wisdom et al., 2006). While considerable research has focused on elk density, elk herbivory pressure, and predation of elk in relation to recruitment and survival of aspen and willow in western North America (Beschta and Ripple, 2010; Ripple and Beschta, 2003, 2007), this work has focused on riparian ecosystems rather than coniferous upland forests, which are the focus of our study.

\section{Study area}

Research was conducted at the Starkey Experimental Forest and Range (SEFR) in the Blue Mountains Ecological Province of northeast Oregon (Fig. 1), approximately $50 \mathrm{~km}$ southwest of La Grande, Oregon $\left(45^{\circ} 12^{\prime} \mathrm{N}, 118^{\circ} 3^{\prime} \mathrm{W}\right)$. The 10,000 -ha Experimental Forest and Range has been the site of long-term studies of cattle, mule deer, and elk during the past 50 years (Rowland et al., 1997; Skovlin, 1991), and is associated with one of the most extensive datasets on ungulate-environmental relations ever accumulated (Rowland et al., 1998; Wisdom, 2005).

Conditions at the SEFR typify those of forest types occurring in interior western North America (Rowland et al., 1997; Wisdom, 2005). Elevations range from 1200 to $1500 \mathrm{~m}$, and mean annual precipitation is approximately $400 \mathrm{~mm}$, with most precipitation occurring as winter snow or spring rain, with a predictable drought during late summer-early fall (Rowland et al., 1997). Forests are composed of Douglas-fir, grand fir, and ponderosa pine (Pinus ponderosa) types (Franklin and Dyrness, 1973), interspersed with grasslands and meadows (Rowland et al., 1997; Wisdom, 2005).

Our study focused on Douglas-fir and grand-fir forest stands in the SEFR. In addition to grand fir and Douglas-fir, other canopy tree species present in these stands include western larch (Larix occidentalis), ponderosa pine, lodge pole pine (Pinus contorta), and Englemann spruce (Picea engelmannii). Common understory grass and grass-like species include Idaho fescue (Festuca idahoensis), elk 


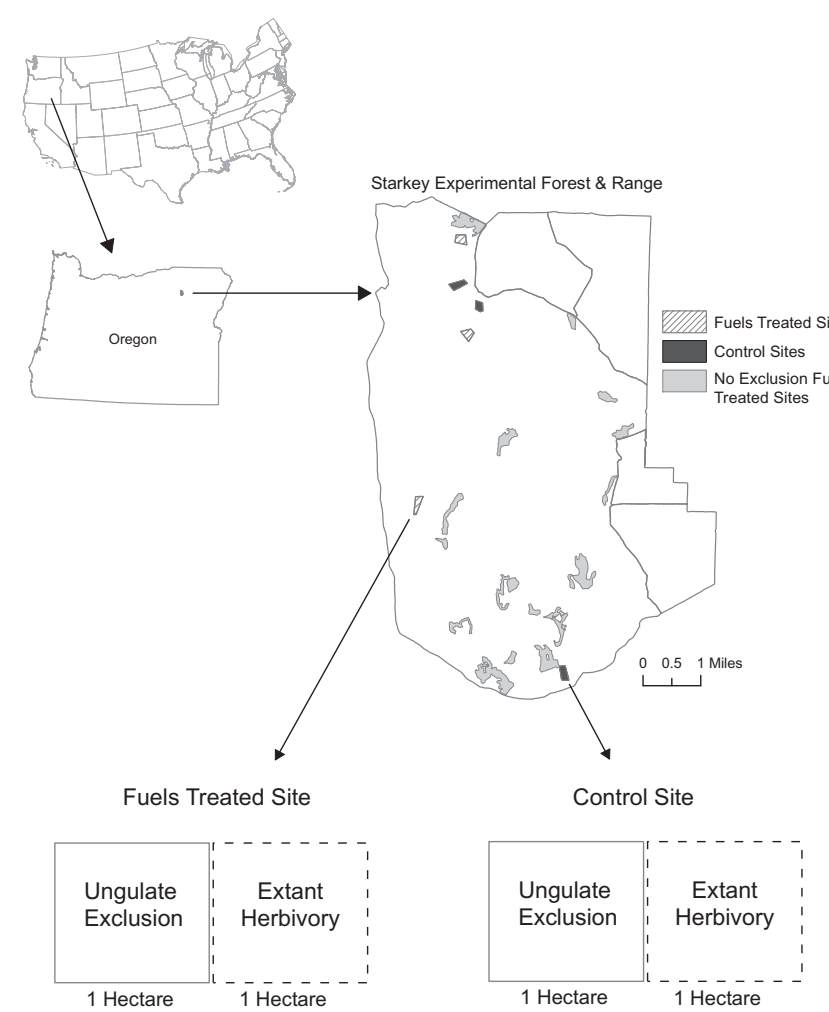

Fig. 1. Starkey Experimental Forest and Range, ungulate herbivory sites, and conceptual layout of the ungulate herbivory experiment. Three sites were fuels treated and burned, and a 1-ha ungulate exclosure constructed at each site, with a paired 1-ha plot established on the same site, but open to extant herbivory by free-ranging cattle, elk, and mule deer. Three other sites of the same vegetation type as treated sites were established as control sites, where no active silviculture had occurred for $>40$ years. Eighteen additional stands were fuels treated but not excluded from ungulate herbivory, and sampled using the same methods used at the experimental fuels treated and control sites.

sedge (Carex geyeri), pinegrass (Calamagrostis rubescens), western fescue (Festuca occidentalis), Kentucky bluegrass (Poa pratensis), and annual bromes (Bromus spp.). Common shrub species include bearberry (Arctostaphylos uva-ursi), big huckleberry (Vaccinium membranaceum), grouse huckleberry (Vaccinium scoparium), rose (Rosa spp.), snowberry (Symphoricarpos albus), shinyleaf spiraea (Spiraea betulifolia lucida), and twinflower (Linnaea borealis). Common forbs include lupine (Lupinus spp.), strawberry (Fragaria spp.), tall annual willowherb (Epilobium paniculatum), and western yarrow (Achillea millefolium).

SEFR has a long history of grazing by domestic and wild ungulates on the area's shared summer range (Skovlin, 1991). During the past 25 years, approximately 500 cow-calf pairs of cattle have grazed SEFR from mid-June through mid-October of each year under a deferred rotation grazing system (Rowland et al., 1997; Wisdom, 2005). During this same period, approximately 200 mule deer and 350 elk (spring population estimates) have grazed the SEFR during spring, summer, and fall (April through November) of each year (Rowland et al., 1997; Wisdom, 2005). Population densities of cattle $\left(7.15 / \mathrm{km}^{2}\right)$, elk $\left(4.55 / \mathrm{km}^{2}\right)$ and mule deer $\left(1.95 / \mathrm{km}^{2}\right)$ at SEFR are typical of densities on shared summer ranges in western North America (Wisdom and Thomas, 1996).

\section{Materials and methods}

\subsection{Silvicultural treatments and exclosure establishment}

During 1999 and 2000, we identified 80 grand fir and Douglasfir stands (between 10 and 50 ha in size) in SEFR for potential application of silvicultural treatments to reduce extremely high fuel loads (Vavra et al., 2004b). The high fuel loads had developed during the late 1980s through the 1990s as a result of an extended outbreak of western spruce budworm (Choristoneura occidentalis), an insect that intensively defoliated and killed nearly all overstory grand fir and Douglas-fir in these stands (Vavra et al., 2004b; Wisdom, 2005). Of the 80 available stands, 46 were randomly selected to apply fuels reduction treatments, with the remaining 34 stands identified as control sites where no silvicultural treatments would be applied.

Silvicultural treatments were applied to the 46 stands between 2000 and 2003 (Bull et al., 2005; Vavra et al., 2004b). Treatments included mechanical thinning of overstory trees and removal of fine conifer fuels in the understory. Before treatment, fuel loads often exceeded 150 tons/ha (Bull et al., 2005).The main treatment objective was to reduce fuel loadings to $<35$ tons/ha, compatible with fuel loads considered unlikely to carry stand-replacement fires (Vavra et al., 2004b, 2007a). All stands were mechanically thinned with a feller-buncher to achieve the objective for overstory removal. Mechanical thinning occurred between May and October of each year. Thirty-eight of the 46 stands were then broadcast burned following mechanical thinning and removal of fuels (Bull et al., 2005). Controlled burns were implemented during the fall of the same year, or on occasion, the following year due to time and logistical constraints. See Bull et al. (2005) for additional details regarding treatment objectives and applications.

Following fuels reduction, six exclosures ranging in size from five to seven hectares were constructed on six different units to exclude all ungulates (Vavra et al., 2004b). Three of the six exclosures were constructed on fuels reduction units subjected to mechanical thinning and broadcast burning (fuels treated sites, Fig. 1). The other three exclosures were constructed on units where no fuels reduction treatments or any other silvicultural treatments had been implemented in $>40$ years (control sites, Fig. 1 ). The control sites were similar in forest structure and composition to pre-treatment conditions of the fuels treated sites. Information on each exclosure, associated management history, and assigned fuels treatment levels, are summarized in Table 1.

The six exclosures were established by constructing an 8-foot high fence that excluded all ungulates (cattle, elk, and mule deer), but allowed for other wildlife to pass under, over, or through. The exclosures were constructed in the year following fuels treatment on each site (Table 1). The size and shape of each exclosure varied with site conditions, including topography, slope, forest structure, and the shape of the forest patch, to minimize site variation within and among exclosures.

We also established a 1-ha paired plot near each exclosure that was subjected to extant herbivory by free-ranging cattle, elk, and mule deer (Fig. 1). These paired extant herbivory areas were located in the same forest types as the associated exclosures, and were subjected to the same background silvicultural treatment (fuels treated or control) as implemented for the associated exclosures (Fig. 1).

\subsection{Data collection}

We sampled the six exclosures during the third growing season after fence construction (Table 1) to identify, count, and measure recruitment of black cottonwood, quaking aspen and willow species. Data collection occurred from 2005 to 2007, depending on the date of exclosure construction. Surveys to locate aspen, cottonwood, and willow species were done with a field crew of 4-6 persons, who systematically searched the exclosures and paired extant herbivory areas on three separate occasions during the first growing season after exclosure construction. When encountered, all individual aspen, cottonwood, and willow were identified, 
Table 1

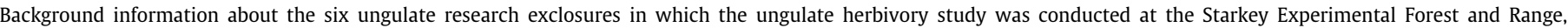
northeast Oregon.

\begin{tabular}{|c|c|c|c|c|}
\hline Exclosure & Size (ha) & Fuels treatment ${ }^{\mathrm{a}}$ date & Exclosure construction date & Sampling date \\
\hline Bally Camp & 6.75 & 2001 & 2002 & 2005 \\
\hline Louis Spring & 7.34 & 2001 & 2002 & 2005 \\
\hline Half Moon & 6.80 & 2002 & 2003 & 2006 \\
\hline Bee Dee & 5.08 & Not treated & 2003 & 2006 \\
\hline Doug Prairie & 7.26 & Not treated & 2003 & 2006 \\
\hline Kaenta Spring & 7.30 & Not treated & 2004 & 2007 \\
\hline
\end{tabular}

${ }^{\text {a }}$ Included partial overstory thinning, removal of fuels on forest floor followed by broadcast burn.

measured, given a unique ID number and tag, and geo-referenced with a global positioning system (GPS) unit (Trimble Pathfinder ProXRS, Trimble Inc., Austin, TX).

Measurements of each individual plant included height $(\mathrm{cm})$, dbh (when applicable for cottonwood and aspen), canopy surface area $\left(\mathrm{cm}^{2}\right)$, and canopy volume $\left(\mathrm{cm}^{3}\right)$. Canopy surface area was estimated by measuring the longest perpendicular length and width measurements along the canopy plane of each plant. Canopy volume was estimated with methods described by Thorne et al. (2002), as derived from the basic ellipsoid volume formula of $\{2 /$ $3 \pi H(A / 2 \times B / 2)\}$ where $H=$ plant height, and $A$ and $B$ are perpendicular diameter measurements taken at $50 \%$ of the plant height across the plane of photosynthetically-active material. This approach overcomes concerns associated with other formulas to estimate canopy volume because it is elastic and accurately accommodates a wide range of plant shapes and sizes (Thorne et al., 2002). This method specifically accommodates a variety of plant shapes that are non-concentric about the horizontal axis and are either compressed or elongated along the vertical access, which are common characteristics of plants in the field, especially browsed plants (Thorne et al., 2002).

We used these same methods to identify, count, and measure recruitment of aspen, cottonwood, and willow present in the paired, one-hectare area adjacent to each exclosure that were subjected to extant herbivory by free-ranging cattle, elk, and mule deer (Fig. 1). Data from these extant areas, in conjunction with data from the exclosures, allowed us to examine the individual and joint effects of ungulate herbivory with episodic disturbances (fuels treatment or control sites) on recruitment, density, and structure of aspen, cottonwood, and willow.

To further expand the inference space of our study, we complemented this dataset by using these same sampling methods to identify and estimate the density and structural development of aspen, cottonwood, and willow in 408 additional plots located within 18 of the 46 units that were fuels treated but not selected for exclosure construction. The 18 additional fuels treatment units were randomly selected from the available fuels treated units. Within the 18 units, sample points were randomly positioned using Hawth's Tools in ArcGIS 9.2 (ArcGIS 9.2, Environmental Systems Research Institute Inc., Redlands, CA). The circular plots, each $167 \mathrm{~m}^{2}$, were located at least $10 \mathrm{~m}$ from the forest edge and $15 \mathrm{~m}$ from the edge of other plots. The number of plots per forest unit varied with size of the units, but all units had a minimum of 5 sampled plots. The total area sampled across the 408 plots was 6.8 ha. At each plot, 2-3 people identified, counted, and measured all aspen, cottonwood, and willow individuals.

\subsection{Data analyses}

Abundance and density of aspen, cottonwood, and willow species were initially calculated for each exclosure and paired extant herbivory area at each fuels treated and control site. Formal analysis of abundance and density data was difficult because of extremely low abundances of most species in the control sites. For example, only four individuals of aspen, cottonwood and other Salix spp. beyond S. scouleriana were encountered in the three control sites. To resolve this issue, we pooled all the species together and conducted a chi-square test of the pooled abundances, testing for differences in the observed versus expected plant abundances between the fuels treated and control sites.

A similar approach was needed to examine differences in abundances between extant and ungulate excluded treatments within the fuels reduction sites. Again, few individuals of most species were found in the extant herbivory treatments, and thus we again pooled species and conducted a chi-square test to evaluate differences in the observed versus expected pooled plant abundances between the extant and ungulate excluded treatments.

In addition, we calculated and graphed the densities of aspen, cottonwood, and all willow species. The willow species were divided into two categories, one containing a single species, Scouler's willow and the other group containing all of the other Salix spp. encountered, including S. boothii, S. bebbiana, S. exigua, S. lasiolepis, S. lucida, and S. monochroma. This was done because all Salix spp. except $S$. scouleriana were not abundant enough on their own for summary. We calculated and graphed these densities for each ungulate exclosure and paired extant herbivory area at each fuels treated and control site. In addition, we calculated and graphed densities for these species across the 18 fuels reduction treatments that had been selected for additional sampling and analysis. These summaries and graphs provided important descriptive insights of the overall patterns of density of the deciduous plant species in response to individual and joint effects of fuels treatment and ungulate herbivory.

We used permutation tests to evaluate differences in the median values of height, canopy surface area, and canopy volume of deciduous species between areas of ungulate exclusion versus areas of extant herbivory in the three fuels treated sites (Bally Camp, Louis Spring, Half Moon). One of the three fuels treated sites (Half Moon) had considerably larger plants than the other two fuels treated sites. Consequently, instead of pooling data from the three sites for analysis, we conducted two sets of permutation tests; one was conducted for Half Moon and the other with data from Louis Spring and Bally Camp combined. We conducted permutation tests for the two most abundant species, Scouler's willow and cottonwood.

Permutation tests were conducted in JMP 9.0 with 2000 resamples (SAS Institute Inc., 2010). For each response variable (height, canopy surface area, volume), individuals were randomly assigned to one of the two treatment groups (areas of ungulate exclusion versus extant herbivory on fuel treated sites) and the medians calculated for each group. This resampling process was done 2000 times, and differences in medians between the two groups were then calculated for each of the 2000 resamples. The permutation distribution and $P$-values were then determined by dividing the number of instances that the permutation median differences from resampling were greater than the observed median difference between the two categories, divided by the total number of resamples. 


\section{Results}

\subsection{Abundance and density in fuels reduction and control treatments}

Large differences in abundance were found between the fuels treated and control sites (Fig. 2), with a significantly greater proportion of aspen, cottonwood, and willow species found in fuels treated sites $\left(X^{2}=119.168, \mathrm{DF}=2, P<0.0001\right)$. These significant differences were reflected in large differences in density of each species or species group between the fuels treated sites and the control sites where no silvicultural treatments were applied (Fig. 2). In all, a total of 2143 individuals were recorded, of which $82 \%$ were found at the fuels treated sites. This resulted in an overall density of deciduous species that was $>4$ times greater in response to fuels reduction (84.4 individuals/ha) compared to control sites (19.7 individuals/ha). Cottonwood was the most abundant species at the fuels treated sites $(N=824)$, and densities ranged from 21.0 to 59.9 plants $/$ ha (median $=41.6$ plants $/$ ha $)$. By contrast, we found only two cottonwoods at the three control sites (range 0-2; median density $=0$ plants $/$ ha).

Salix spp. and quaking aspen followed a similar pattern and were nearly absent at the control sites, with only two Salix spp. and no aspen encountered. Densities of Scouler's willow also were higher at the fuels reduction sites (median $=32.4$ plants $/$ ha; range $=32.4-36.6$ plants $/$ ha) than at control sites (median $=$ 17.7 plants/ha; range $=7.7-32.4$ plants/ha).

\subsection{Ungulate herbivory and fuels reduction interactions}

Within the fuels reduction sites, a significantly higher abundance of aspen, cottonwood, and willow were found when ungulates were excluded $\left(X^{2}=142.875, \mathrm{DF}=2, P<0.0001\right.$; Fig. 3$)$. These significant differences were reflected in large differences in the density of each species or species group between fuels treated sites excluded from ungulate herbivory versus fuels treated sites subjected to extant herbivory (Fig. 3). Densities of cottonwood were $>5$ times higher in exclosures on fuels treated sites (122.5 stems/ha) versus the paired areas of extant herbivory (24.3 stems/ha). Density patterns for the other species followed the same trend. Populus spp. and Salix spp. had a combined density

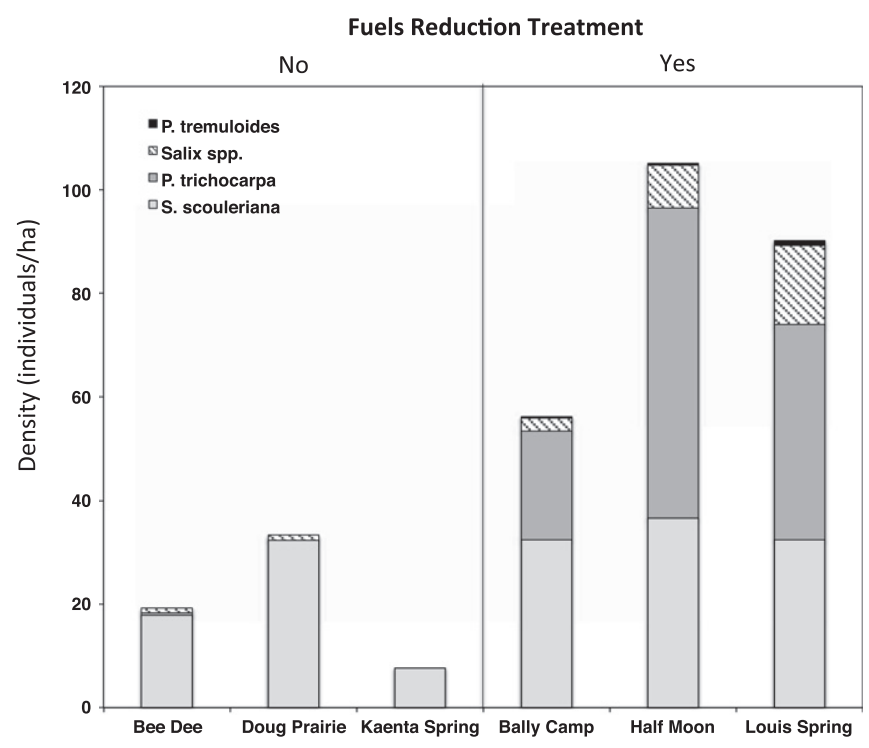

Fig. 2. Density of aspen, cottonwood, and willow species in three ungulate exclosures subjected to fuels reduction treatments (fuels treated sites, right side) versus three ungulate exclosures not subjected to fuels reduction treatments (control sites, left side). of 211.6 stems/ha within the exclosures compared with a density of 66.1 stems/ha in areas of extant herbivory.

Results from the additional 18 fuels reduction forest stands further supported the findings from our controlled experiment that Populus spp. and Salix spp. densities are disproportionately higher following fuels reduction when ungulates are excluded. Of the 6.8 ha sampled across the 18 stands, only 85 individuals were encountered, nearly all of which were Scouler's willow $(N=76)$. Seven cottonwoods and one Salix spp. were also encountered, while no aspen were found. Plant densities in these stands were also much lower than in the exclosures: density of Scouler's willow ranged from 0 to 25 (median $=7.6 / \mathrm{ha}$ ), followed by cottonwood (median =0/ha; range: 0-17.1) and Salix spp. (median =0; range $0-1.3$ ). Evidence of past herbivory was prevalent and $89 \%$ of plants encountered showed evidence of past ungulate browsing.

Results from our permutation tests also revealed that deciduous species subjected to extant ungulate herbivory were significantly smaller in height, canopy surface area, and canopy volume than the same species inside the ungulate exclosures (Figs. 4 and 5). Height, canopy surface area, and plant volume were significantly different for cottonwood. Cottonwood showed the greatest differences in height, while Scouler's willow showed greatest differences in canopy surface area and volume.

\section{Discussion and management implications}

Our results demonstrated the benefits of episodic ground disturbances in facilitating recruitment of deciduous plant species that are highly palatable to ungulates in forests of interior western North America (Irwin and Peek, 1983). In our study, fuels reduction and burning were key episodic disturbances that facilitated recruitment of aspen, cottonwood and willow. By contrast, areas of ungulate exclusion at control sites, in the absence of episodic disturbances, resulted in little recruitment of aspen, cottonwood, or any species of willow except Scouler's willow.

Effects of ungulate herbivory on density and structural development of aspen, cottonwood, and willow also were dependent on the prior benefits of fuels reduction and burning that facilitated recruitment and growth of these deciduous plant species, particularly in the absence of ungulate herbivory. These results support hypotheses and associated models that have described the potential synergy

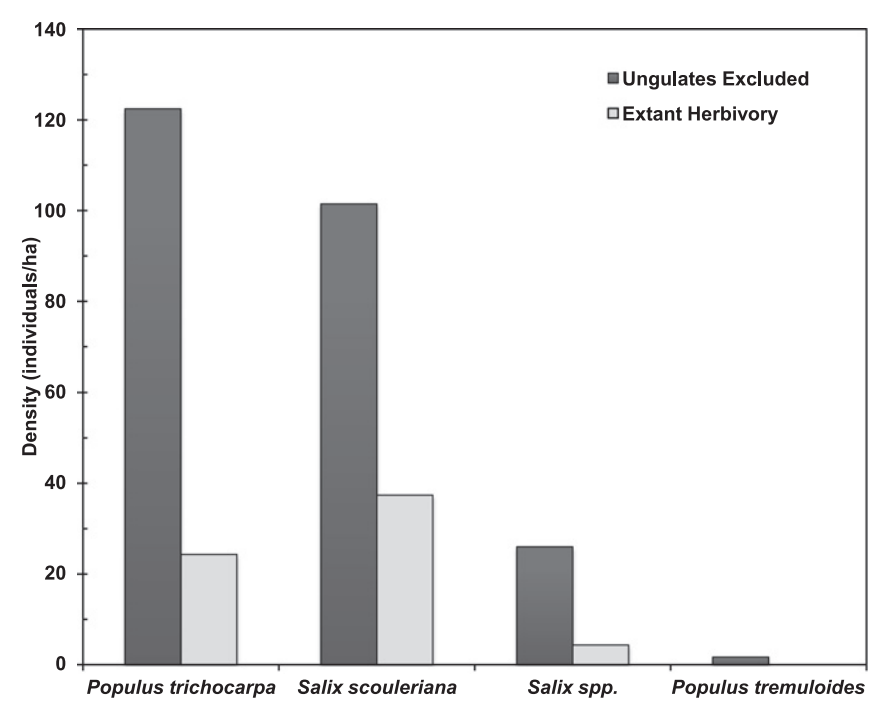

Fig. 3. Density of aspen, cottonwood, and willow species in three fuels treated sites subjected to either extant herbivory by cattle, elk, and mule deer, or excluded from all ungulate grazing. Data from the three fuels treated sites (Bally Camp, Half Moon, and Louis Spring) were pooled for this analysis. 


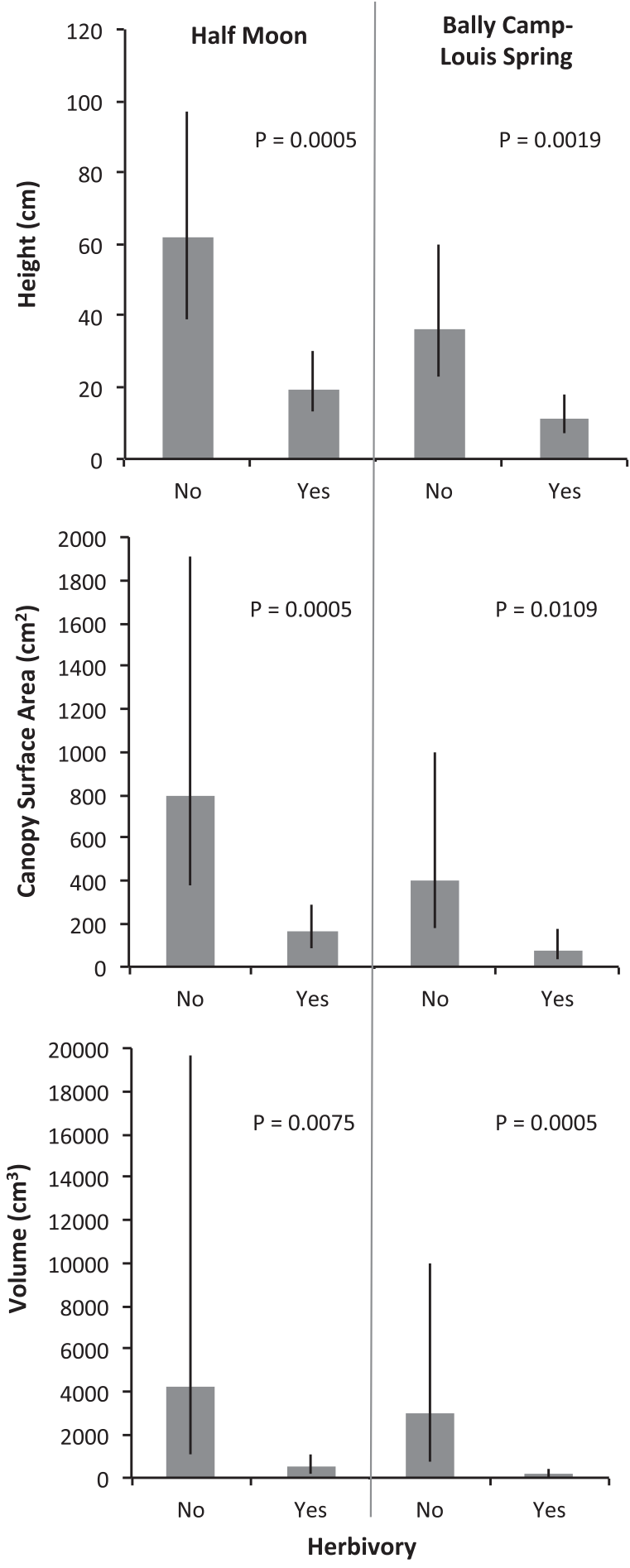

Fig. 4. Median height, canopy surface area, and canopy volume of cottonwood $(P$. trichocarpa) found in the fuels treated sites excluded from ungulate herbivory versus the 1-ha paired areas subjected to extant herbivory by cattle, elk, and mule deer. Data from Bally Camp and Louis Springs sites are pooled. All areas were subjected to fuels reduction treatments. $P$-values show significant differences in medians from permutation tests. The interquartile range (25-75\%) is also displayed to highlight data variability.

of ungulate herbivory with episodic disturbances in changing the composition and structure of aspen, cottonwood, and willow in forests of interior western North America (Vavra et al., 2007a,b; Wisdom et al., 2006). These hypotheses and associated models suggest that episodic disturbances initially favor recruitment of

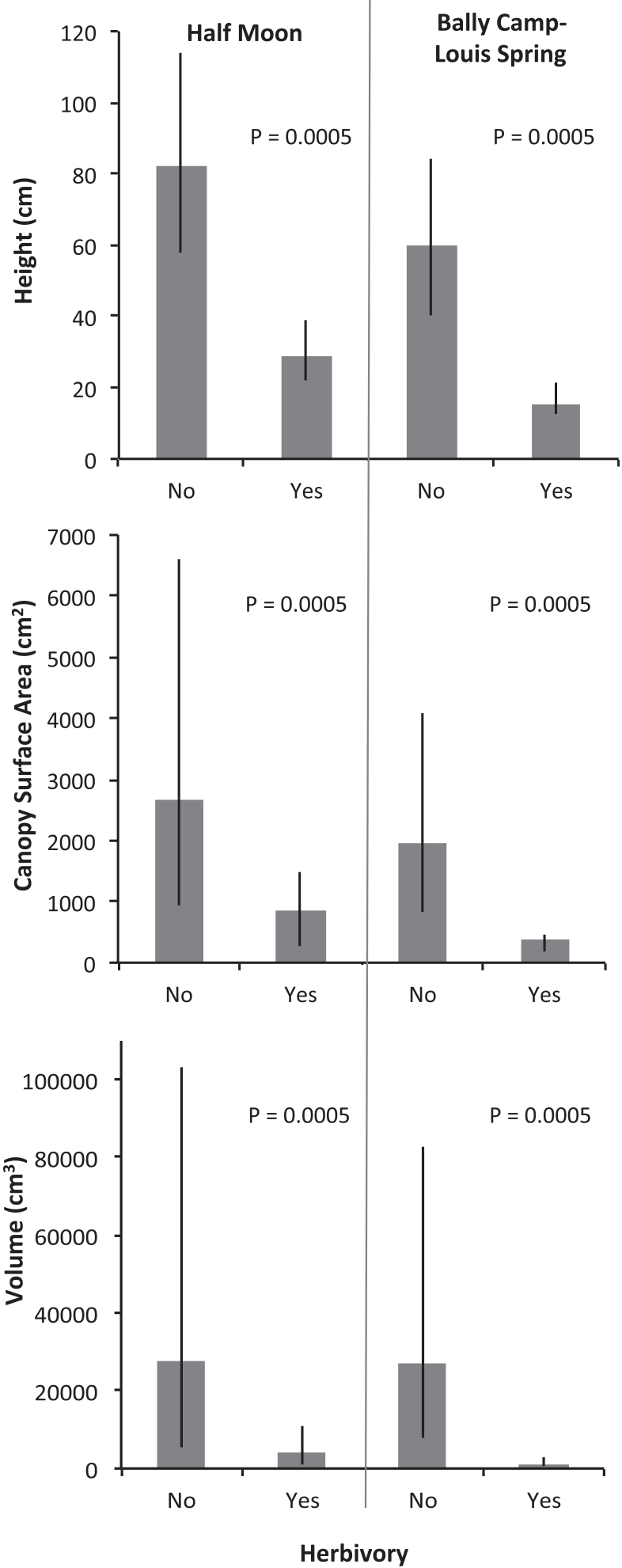

Fig. 5. Median height, canopy surface area, and canopy volume of Scouler's willow (S. scouleriana) found in the fuels treated sites excluded from ungulate herbivory versus the 1-ha paired areas subjected to extant herbivory by cattle, elk, and mule deer. Data from Bally Camp and Louis Springs sites are pooled. All areas were subjected to fuels reduction treatments. P-values show significant differences in medians from permutation tests. The interquartile range (25-75\%) is also displayed to highlight data variability.

deciduous plants that are highly palatable to ungulates. In turn, areas of episodic disturbance become focal points for ungulate herbivory. The resulting high level of chronic ungulate herbivory then 
reduces or eliminates the palatable deciduous plant species in such areas, and in the process, favors in-growth of unpalatable conifers. In-growth of unpalatable conifers results in a substantial increase in volume of understory ladder fuels, in turn increasing the probability, intensity, and extent of stand-replacement wildfires (Vavra et al., 2007a,b). Long-term studies, spanning multiple decades of forest development, are needed to evaluate these relationships empirically (Wisdom et al., 2006).

Ungulate herbivory can dramatically affect the density and structure of aspen, cottonwood, and willow in areas of high recruitment of these species after episodic disturbance. Our results further demonstrate that reductions in density and structure of these highly nutritious plant species can occur over very short time periods, immediately following ground disturbances that facilitate recruitment of these deciduous species. It is likely that in many coniferous forests of western North America, that the absence of aspen, cottonwood, and willow species as understory species may reflect the very short time periods over which these plant species can be substantially reduced or eliminated in response to high ungulate herbivory that typically follows episodic ground disturbances.

Our results further suggest that aspen, cottonwood, and willow species are potentially common components of upland forests of grand fir and Douglas-fir communities of interior western North America. This pattern is new and surprising, given that these deciduous species are common on wetter sites, especially riparian areas, but not considered common in upland coniferous forests (Franklin and Dyrness, 1973; Johnson and Simon, 1997). For example, other than Scouler's willow, none of our other study species (cottonwood, aspen, other willow species) are even mentioned as components of Douglas-fir and grand fir forest in the region (Johnson and Simon, 1997). Yet cottonwoods were the most of the abundant species measured in fuels treated areas when ungulates were excluded. Additional research is needed to determine if seedlings of cottonwood, willow, and aspen continue to persist as succession continues following episodic disturbances.

Aspen, cottonwood, and willow species can exist as shrubs or trees, and our results indicate that these species have the potential to be dominant or co-dominant members of upland forest sites previously considered as strictly coniferous forest types. Recruitment and long-term survival of aspen, cottonwood, and willow species in these upland forests are likely to require a combination of episodic disturbance such as silviculture and fire to facilitate plant recruitment, followed by reductions in grazing pressure by domestic and wild ungulates between periods of episodic disturbance to facilitate long-term plant growth and survival (Romme et al., 1995; Vavra et al., 2007a). The recruitment and establishment of deciduous species of high nutritional value to ungulates is greatly influenced not only by the distribution and abundance of ungulates, but also by the size, shape, and distribution of episodic disturbances and subsequent forage areas across the landscape (Wisdom and Thomas, 1996). For example, small, isolated disturbances (e.g., small scale fuels reduction treatments) may concentrate ungulate herbivory in small areas thereby suppressing or eliminating these species from the landscape, while larger or more frequent disturbances (e.g., wildfire) may spread ungulate herbivory across the landscape, thereby increasing the likelihood that species can escape herbivory and successfully establish. Alternatively, small, fragmented patches created by smaller disturbances may create a landscape where some patches are undetected by ungulates, resulting in greater dominance of the deciduous trees species in certain areas. Thus, the management implications are potentially profound.

Further evaluation of our findings will require manipulative, controlled experiments that vary the density levels of each ungulate in relation to episodic disturbances to identify potential threshold densities of ungulates, above which the establishment and growth of aspen, cottonwood, and willow species are substantially affected, and below which the growth and survival of these deciduous species is likely (Wisdom et al., 2006). Our experiment did not evaluate the effects of different density levels of ungulates beyond complete exclusion versus extant herbivory, and thus our work could not be used to identify potential threshold densities of ungulates. Deciduous plant responses to multi-density manipulation of ungulates remains a strong and unmet need. Moreover, it remains unclear if cottonwood, aspen, and willow establishment and survival will continue as forest succession progresses, or if other environmental or biotic factors reduce survival. Such longterm experiments are needed to gain quantitative knowledge about the specific combinations of episodic ground disturbances and levels of ungulate herbivory needed to meet vegetation management goals in upland forests of interior western North America.

\section{Acknowledgments}

We thank 12 summer technicians who helped collect field data for our work. In addition, we thank Ryan Kennedy and Dennis Rea for logistical support of our research, and Tim DelCurto, John Cook, and Rachel Cook for their suggestions on research designs. Laura Schultz provided JMP scripts for permutation procedures. Our research was funded by the USDA Forest Service Pacific Northwest Research Station, Blue Mountains Demonstration Project, Oregon State University, and the Institute for Conservation Research, San Diego Zoo Global. Research was conducted under approval and guidance by an Institutional Animal Care and Use Committee (IACUC 92-F-0004), as required by the United States Animal Welfare Act of 1985 and its regulations. We followed protocols established specifically by the IACUC for conducting cattle, elk, and mule deer research in our study area (Wisdom et al., 1993).

\section{References}

Alverson, W.S., Waller, D.M., 1997. The white tailed deer: a keystone herbivore. Wildl. Soc. Bull 25, 217-226.

Augustine, D.J., Frelich, L.E., Jordan, P.A., 1998. Evidence for to alternate stable states in an ungulate grazing system. Ecol. Appl. 8, 1260-1269.

Bartos, D.L., 2001. Landscape dynamics of aspen and conifer forests. In: USDA Forest Service Rocky Mountain Research Station Proceedings RMRS-P-18, Logan, UT, USA

Beschta, R.L., 2005. Reduced cottonwood recruitment following extirpation of wolves in Yellowstone's northern range. Ecology 86, 391-403.

Beschta, R.L., Ripple, W.J., 2010. Recovering riparian plant communities with wolves in northern Yellowstone, USA. Restor. Ecol. 18, 380-389.

Bormann, B.T., Gordon, J.C., 1989. Can intensively managed forest ecosystems be self-sufficient in nitrogen? Forest Ecol. Manag. 29, 95-103.

Brookshire, E.N.J., Kaufman, J.B., Lytjen, D., Otting, N., 2002. Cumulative effects of wild ungulate and livestock herbivory on riparian willows. Oecologia 132, 559566.

Bull, E.L., Clark, A.A., Shepherd, J.F., 2005. Short-term effects of fuel reduction on pileated woodpeckers in northeastern Oregon - a pilot study. USDA Forest Service, Pacific Northwest Research Station. Res. Pap. PNW-RP-564. Portland, OR.

Canon, S.K., Urness, P.J., DeBule, N.V., 1987. Foraging behavior and dietary nutrition of elk in burned aspen forest. J. Range Manag. 40, 433-438.

Cook, J.G., 2002. Nutrition and food. In: Toweill, D.E., Thomas, J.W. (Eds.), North American Elk, Ecology and Management. Smithsonian Institution Press, Washington, DC, pp. 259-349.

Côté, S.D., Rooney, T.P., Tremblay, J.P., Dussault, C., Waller, D.M., 2004. Ecological impacts of deer overabundance. Ann. Rev. Ecol. Evol. Syst. 35, 113147.

deCalesta, D.S., 1994. Effects of white-tailed deer on songbirds within managed forests in Pennsylvania. J. Wildl. Manag. 58, 711-718.

Díaz, S., Lavorel, S., McIntyre, S., Falczuk, V., Casanoves, F., Milchunas, D.G., Skarpe, C., Rusch, G., Sternberg, M., Noy-Meir, I., Landsberg, J., Zhang, W., Clark, H., Campbell, B.D., 2007. Plant trait responses to grazing - a global synthesis. Global Change Biol. 13, 313-331.

Fleischner, T.L., 1994. Ecological costs of livestock grazing in Western North America. Conserv. Biol. 8, 629-644.

Franklin, J.F., Dyrness, C.T., 1973. Natural vegetation of Oregon and Washington. USDA Forest Service, Pacific Northwest Forest and Range Experiment Station. Gen. Tech. Rep. PNW-GTR-8, Portland, OR. 
Hann, W.J., Jones, J.L., Karl, M.G., Hessburg, P.F., Keane, R.E., Long, D.G., Menakis, J.P., McNicoll, C.H., Leonard, S.G., Gravenmier, R.A., Smith, B.G., 1997. Landscape dynamics of the basin. In: Quigley, T.M., Arbelbide, S.J. (Tech. Eds.), An Assessment of Ecosystem Components in the Interior Columbia Basin and Portions of the Klamath and Great Basins. USDA Forest Service, Pacific Northwest Research Station. Gen. Tech. Rep. PNW-GTR-405, Portland, OR. pp. 337-1055.

Hessl, A.E., Graumlich, L.J., 2002. Interactive effects of human activities, herbivory and fire on quaking aspen (Populus tremuloides) age structures in western Wyoming. J. Biogeogr. 29, 889-902.

Hobbs, N.T., 1996. Modification of ecosystems by ungulates. J. Wildl. Manag. 60, 695-713.

Irwin, L.L., Peek, J.M., 1983. Elk habitat use relative to forest succession in Idaho. J. Wildl. Manag. 47, 664-672.

Johnson, C.G., Simon, S.A., 1997. Plant associations of the Wallowa-Snake Province. Gen. Tech. Rep.R6-ECOL-TP-255A-86, Portland, OR.

Kay, C.E., 1997a. Viewpoint: ungulate herbivory, willows, and political ecology in Yellowstone. J. Range Manag. 50, 139-145.

Kay, C.E., 1997b. Is aspen doomed? J. Forestry 95, 4-11.

Knops, M.H., Ritchie, M.E., Tilman, D., 2000. Selective herbivory on a nitrogen fixing legume (Lathyrus venosus) influences productivity and ecosystem nitrogen pools in an oak savanna. Ecoscience 7, 166-174.

McShea, W.J., Rappole, J.H., 2000. Managing the abundance and diversity of breeding bird populations through manipulation of deer populations. Conserv. Biol. 14, 1161-1170.

Pastor, J., Cohen, Y., 1997. Herbivores, the functional diversity of plants species, and the cycling of nutrients in ecosystems. Theoret. Popul. Biol. 51, 1-15.

Pastor, J., Dewey, B., Naiman, R.J., McInnes, P.F., Cohen, Y., 1993. Moose browsing and soil fertility in the Boreal Forest of Isle Royale National Park. Ecology 74, 467-480.

Quigley, T.M., Arbelbide, S., 1997. An assessment of ecosystem components in the interior Columbia Basin and portions of the Klamath and Great Basins. USDA Forest Service, BLM, Pacific Northwest Region. Gen. Tech. Rep. PNW-GTR-405. Portland, OR.

Riggs, R.A., Tiedemann, A.R., Cook, J.G., Ballard, T.M., Edgerton, P.J., Vavra, M., Krueger, W.C., Hall, F.C., Bryant, L.D., Irwin, L.L., DelCurto, T., 2000. Modification of mixed-conifer forests by ruminant herbivores in the Blue Mountains Ecological Province. USDA Forest Service, Pacific Northwest Research Station. Res. Pap. PNW-RP-527. Portland, OR.

Ripple, W.J., Beschta, R.L., 2003. Wolf reintroduction, predation risk, and cottonwood recovery in Yellowstone National Park. Forest Ecol. Manag. 184, 299-313.

Ripple, W.J., Beschta, R.L., 2007. Restoring Yellowstone's aspen with wolves. Biol. Conserv. 138, 514-519.

Romme, W.H., Turner, M.G., Wallace, L.L., Walker, J.S., 1995. Aspen, elk, and fire in northern Yellowstone National Park. Ecology 76, 2097-2106.

Rowland, M.M., Bryant, L.D., Johnson, B.K., Noyes, J.H., Wisdom, M.J., Thomas, J.W., 1997. The Starkey Project: history, facilities, and data collection methods for ungulate research. USDA Forest Service, Pacific Northwest Research Station. Gen. Tech. Rep. PNW-GTR-396. Portland, OR.

Rowland, M.M., Coe, P.K., Stussy, R.J., Ager, A.A., Cimon, N.J., Johnson, B.K., Wisdom, M.J., 1998. The Starkey habitat data base for ungulate research: construction, documentation, and use. USDA Forest Service, Pacific Northwest Research Station. Gen. Tech. Rep. PNW-GTR-430. Portland, OR.
SAS Institute Inc., 2010. JMP, Version 9.0. Cary, North Carolina.

Schoenecker, K.A., Singer, F. Zeigenfuss, L.C., Binkley, D., Menezes, R.S.C., 2004 Effects of elk herbivory on vegetation and nitrogen processes. J. Wildl. Manag. $68,837-849$.

Sinclair, A.R.E., 2003. Mammal population regulation, keystone processes, and ecosystem dynamics. Philos. Trans. Royal Soc. Lond. Biol. Sci. 358, 1729-1740.

Skovlin, J.M., 1991. Fifty years of research progress: a historical document on the Starkey Experimental Forest and Range. USDA Forest Service Pacific, Northwest Research Station. Gen. Tech. Rep. PNW-GTR-266. Portland, OR.

Smit, C., Putman, R., 2011. Large herbivores as environmental engineers. In: Putman, R., Apollonio, M., Andersen, R. (Eds.), Ungulate Management in Europe: Problems and Practices. Cambridge University Press, Cambridge, UK, pp. 260-283.

Thorne, M.S., Skinner, Q.D., Smith, M.A., Rodgers, J.D., Laycock, W.A., Cerekci, S.A. 2002. Evaluation of a technique for measuring canopy volume of shrubs. J. Range Manage. 55, 235-241.

Tiedemann, A.R., Berndt, H.W., 1972. Vegetation and soils of a 30-year deer and elk exclosure in central Washington. Northw. Sci. 46, 59-66.

Vavra, M., Ager, A.A., Johnson, B., Wisdom, M.J., Hemstrom, M.A., Riggs, R., 2004a Modeling the effects of large herbivores. In: Hayes, J.L., Ager, A.A., Barbour, J.R. (Tech. Eds.), Methods for Integrated Modeling of Landscape Change: Interior Northwest Landscape Analysis System. USDA Forest Service, Pacific Northwest Research Station. Gen. Tech. Rep. PNW-GTR-610. Portland, OR, pp. 82-103.

Vavra, M., Wisdom, M.J., Kie, J.G., Cook, J.G., Riggs, R.A., 2004b. The role of ungulate herbivory and management on ecosystem patterns and processes: future direction of the Starkey Project. Trans. North Am. Wildl. Nat. Res. Conf. 69, 785797.

Vavra, M., Hemstrom, M.A., Wisdom, M.J., 2007a. Modeling the effects of herbivores on the abundance of forest overstory states using a state-transition approach in the upper Grande Ronde River Basin, Oregon, USA. Lands. Urban Plann. 80, 212222.

Vavra, M., Parks, C.G., Wisdom, M.J., 2007b. Biodiversity, exotic plant species, and herbivory: the good, the bad, and the ungulate. Forest Ecol. Manag. 246, 66-72.

Wardle, D.A. 2002. Communities and ecosystems: linking the aboveground and belowground components. Monographs in population biology 34. Princeton University, Princeton, New Jersey, USA.

Weisberg, P.J., Bugmann, H., 2003. Forest dynamics and ungulate herbivory: from leaf to landscape. Forest Ecol. Manage. 181, 1-2

White, C.A., Olmsted, C.E., Kay, C.E., 1996. Aspen, elk, and fire in the Rocky Mountain national parks of North America. Wildl. Soc. Bull. 26, 449-462.

Wisdom, M.J., Cook, J.G., Rowland, M.M., Noyes, J.H., 1993. Protocols for care and handling of deer and elk at the Starkey Experimental Forest and Range. USDA Forest Service, Pacific Northwest Research Station. Gen. Tech. Rep. PNW-GTR311. Portland, Oregon.

Wisdom, M.J., Thomas, J.W., 1996. Elk. In: Krausman, P.R. (Ed.), Range Land Wildlife. Society for Range Management, Denver, CO, pp. 157-181.

Wisdom, M.J. (Tech. Ed.), 2005. The Starkey Project: A Synthesis of Long-term Studies of Elk and Mule Deer. Alliance Communications Group, Allen Press, Lawrence, KS, USA

Wisdom, M.J., Vavra, M., Boyd, J.M., Hemstrom, M.A., Ager, A.A., Johnson, B.K., 2006. Understanding ungulate herbivory-episodic disturbance effects: knowledge gaps and management needs. Wildl. Soc. Bull. 34, 283-292. 